\title{
Volwaardig werk voor mensen met een beperking
}

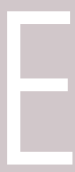

en inclusieve arbeidsmarkt waarin óók mensen met een beperking volwaardig kansen krijgen om mee te doen. Wat dat betekent, staat opnieuw ter discussie, nu het kabinet met een voorstel voor loondispensatie is gekomen. Ik vind het belangrijk dat werknemers met een beperking een volwaardige baan hebben, met daarbij horend salaris, inclusief recht op WW en pensioen. Zodat ze hetzelfde worden behandeld als hun collega's en dus niet 'anders' zijn vanwege hun beperking.

Daarom ben ik tegen het instrument loondispensatie. Met loondispensatie krijgen werknemers met een beperking alleen salaris voor de productiviteit die ze leveren. De rest van het inkomen moet worden aangevuld vanuit een bijstandsuitkering. Wat betekent dat voor mensen met een beperking? Het betekent dat ze hun leven lang afhankelijk blijven van een uitkering. Dat ze nauwelijks WW en geen pensioen opbouwen. En dat ze worden opgezadeld met een hoop administratief gedoe, zoals maandelijkse verrekeningen: de inkomsten van de partner en elke wijziging in loonwaarde kan consequenties hebben voor salaris en uitkering. Dat is complex en een recept voor fouten. Met als gevolg terugvorderingen, en grotere kansen op het ontstaan van schuldsituaties.

\section{Inzicht}

Maar het betekent vooral dat werknemers met een beperking nooit een volwaardig werknemer worden. Ze werken net zo veel en net zo hard, maar ze worden vanwege hun beperking anders behandeld dan hun collega's. Dat is ook de reden dat het College voor de Rechten van de Mens loondispensatie in strijd vindt met het internationaal recht: artikel 27 van het VN-verdrag borgt gelijke behandeling van werknemers. En dan zijn er nog een heleboel mensen, die niet eens in aanmerking komen voor een aanvullende bijstandsuitkering. Omdat ze een werkende partner hebben bijvoorbeeld, of spaargeld. Of omdat ze net van school komen en nog geen recht hebben op een uitkering. Voor deze mensen is het voorstel helemaal schrijnend: zij kunnen nooit een volledig inkomen verkrijgen. Het gaat hier om tenminste 30.000 mensen. Het protest tegen loondispensatie is dan ook massaal en daar ben ik blij om. Veel maatschappelijke organisaties en mensen uit de doelgroep bestoken de politiek. Er is een petitie gestart die door ruim 83.000 mensen is ondertekend. (aantal op laatste moment actualiseren).

De politiek toont zich terecht niet helemaal ongevoelig voor het maatschappelijk protest. In het debat over de hoofdlijnennotitie van staatssecretaris Van Ark van Sociale Zaken en Werkgelegenheid is afgesproken om nog eens goed te kijken naar de nadelen van loondispensatie en manieren om die te voorkomen of af te zwakken. Het gaat dan vooral om de hiervoor genoemde partnertoets. Dat zou mooi zijn, maar gaat voorbij aan de kern van de discussie: met loondispensatie wordt iemand met een beperking nooit een volwaardig werknemer.

Cedris pleit er daarom voor het huidige instrument loonkostensubsidie te verbeteren. Bij loonkostensubsidie krijgt de werkgever subsidie van de gemeente om de werknemer met een beperking een volledig salaris te kunnen betalen. Dat instrument werkt op zichzelf goed, maar kent onnodige bureaucratie en administratieve lasten voor de werkgever. Maar daar is gelukkig wat aan te doen. Cedris heeft hiervoor een aantal voorstellen gedaan. Die voorstellen zijn positief ontvangen door een groot aantal organisaties en ook enkele politieke partijen. Ik hoop daarom van harte dat de coalitie hier serieus naar wil gaan kijken. Zodat die inclusieve arbeidsmarkt waarin mensen met een beperking volwaardig werknemer zijn, ook echt in zicht komt.

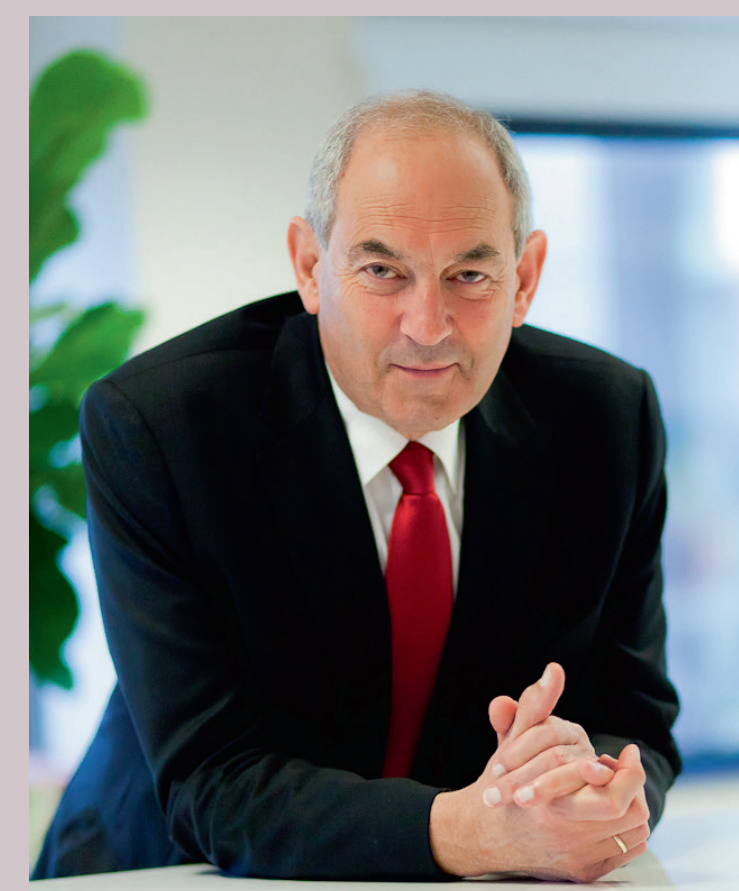

De politiek

toont zich

niet ongevoelig

voor het

protest tegen

loondispensatatie. 